\title{
Effect of Abiotic Factors on Oyster Mushroom Production (Pleurotus Species)
}

\author{
K. Chitra*, B. Sathyaparvathavarthini, S. Mahalakshmi, R. Kamali, \\ P.T. Sharavanan, C. Balisasikumar and K. Dhanalakshmi \\ Anbil Dharmalingam Agricultural College and Research Institute, Trichy-27, India \\ *Corresponding author
}

\section{Keywords}

Mycelial growth, Relative humidity, Temperature Pleurotus species.

Article Info

Accepted:

08 June 2018

Available Online:

10 July 2018

\section{A B S T R A C T}

Oyster mushroom (Pleurotus spp.) is fungal fruiting body. There are several oyster mushroom varieties available. Some of the varieties were commercially cultivating in Tamil Nadu. The mushrooms will give good yield based on the climatic condition especially temperature and relative humidity. A study was undertaken for identifying effect of temperature and relative humidity on oyster mushroom production exclusive for Trichy district. The high yield of oyster mushroom mainly depends upon temperature and relative humidity. The isolation is made from mushroom. The mushroom isolation was done for pure culturing of mushroom. These isolates were cultured in PDA medium. The paddy straws and paddy seeds were used for mushroom and spawn production. The spawn production and the mushroom production mainly depends upon temperature and relative humidity, however the temperature and relative humidity of December and January months are more favorable for mushroom growth compared to March and April. The high yield was recorded in December and January compared to February while during the project period. The results showed that temperature and relative humidity are the main climatic factors that alter the mushroom yield.

\section{Introduction}

Oyster mushroom (Pleurotus sp.) belonging to Class Basidiomycetes and Family Agaricaceae is popularly known as 'dhingri' in India and grows naturally in the temperate and tropical forests on dead and decaying wooden logs or sometimes on dying trunks of deciduous or coniferous woods. The oyster mushrooms have three distinct parts - a fleshy shell or spatula shaped cap (pileus), a short or long lateral or central stalk called stipe and long ridges and furrows underneath the pileus called gills or lamellae. The gills stretch from the edge of the cap down to the stalk and bear the spores $(1,2,3)$. The spores are smooth, cylindrical and germinate very easily on any kind of mycological media within 48-96 hrs. The mycelium of Pleurotus is pure white in colour. It may also grow on decaying organic matter. The fruit bodies of this mushroom are distinctly shell or spatula shaped with different shades of white, cream, grey, yellow, pink or light brown depending upon the species. 
It is one of the most suitable fungal organisms for producing protein rich food from various agro-wastes or forest wastes without composting. Cultivation of a sp. of oyster mushroom (Pleurotus ostreatus) was initiated on experimental basis in Germany by Flack during the year 1917 on tree stumps and wood logs(4-7). Growing technology was perfected in USA by Block, Tsao and Hau. Oyster mushroom can grow at moderate temperature ranging from 20 to $30^{\circ} \mathrm{C}$ and humidity 55$70 \%$ for a period of 6 to 8 months in a year. It can also be cultivated in summer months by providing the extra humidity required for its growth. In hilly areas above $900 \mathrm{~m}$ (M.S.L.), the best growing season is during March/April to September/October and in the lower regions from September/October to March/April. Like Temperature, Relative humidity is important to the growth and development. Keeping these objectives in view present investigation was taken up.

\section{Materials and Methods}

In the present work lignocellulosic substrates viz. paddy straw along with the oyster mushroom - Pleurotus florida was selected. Experiment was conducted on solid media to study the effect of temperature and relative humidity on the mycelia growth of Pleurotus species. The mushrooms were grown on lignocellulosic substrates at different temperature ranging from $22^{\circ} \mathrm{C}-42^{\circ} \mathrm{C}$ ) and relative humidity ranging from $55 \%, 79 \%$ in solid medium.

Solid medium was prepared using $2 \%$ agaragar and $0.3 \%$ lignocellulosic substrate in distilled water. The medium was warmed till the agar was dissolved in the distilled water and then autoclaved at $121^{\circ} \mathrm{C}$ and $15 \mathrm{psi}$ pressure for 20 minutes. The $\mathrm{pH}$ of the medium was adjusted at 6.0 and 6.5 and $10 \mathrm{ml}$ medium was poured in each petri plate $(9 \mathrm{~cm}$ diameter) under in vitro condition. The medium was allowed to solidify in petriplates.
After solidification $5 \mathrm{~mm}$ plug of 10 days old culture was inoculated. The inoculum was cut out with the help of cork borer, which was fully sterilized. The growth of Pleurotus species mycelium was measured in term of radial distance at three days interval till the petriplates were completely covered. The experiments were conducted at the temperature of $20^{\circ} \mathrm{C}, 25^{\circ} \mathrm{C}, 30^{\circ} \mathrm{C}, 35^{\circ} \mathrm{C}$ and $40^{\circ} \mathrm{C}$ and at the relative humidity of $.80 \%$, $75 \%, 70 \%, 65 \%$ and $60 \%$

\section{Results and Discussion}

Growth of the mushroom were showed relatively high on the solid media which grown on lignocellulosic substrates at different temperature ranging from $22^{\circ} \mathrm{C}-42^{\circ} \mathrm{C}$ and relative humidity $59 \%-79 \%$. The mycelial growth was completely filled by mycelium within 11 to 13 days or before 15 days on the paddy straw substrate. Among this temperature Dec, Jan month $\left(22^{\circ} \mathrm{C}-24^{\circ} \mathrm{C}\right)$ and Relative Humidity (74\% - 79\%) showed better growth than other months (Oct, Nov, March, April and May). In Dec, and Jan month the temperature and relative Humidity supported faster growth positively than the other months and May month temperature $\left(35^{\circ} \mathrm{C}-42^{\circ} \mathrm{C}\right)$ and Relative Humidity (55\% - 68\%) negatively correlated because growth was declined.

Maximum mycelial growth of Pleurotus florida was recorded at $22^{0} \mathrm{C}$ to $24^{0} \mathrm{C}$, this were completely filled on paddy straw in 1113 days. Temperature ranging from $28^{\circ} \mathrm{C}$ $42^{0} \mathrm{C}$ slow and thin mycelial growth was recorded during the period and slightly temperature raises yield was declined. Among this period, April and May $\left(35^{\circ} \mathrm{C}\right.$ and $\left.40^{\circ} \mathrm{C}\right)$ showed high temperature land low relative humidity resulted in slow growth on the solid media which contain a paddy straw substrate. This leads to malformed mushroom due to high temperature and low relative humidity (Table 1-8). 
The effect of temperature on the mycelial growth of Pleurotus florida (Per 5 bags) Table.1 Month of October

\begin{tabular}{|c|c|c|c|}
\hline Weekly Data & Temperature $\left({ }^{\circ} \mathrm{C}\right)$ & Relative Humidity (\%) & Yield of Mushroom (Kg) \\
\hline $1^{\text {st }}$ week & 23.5 & 72 & $900 \mathrm{~g}$ \\
\hline $2^{\text {nd }}$ week & 26 & 73.5 & $1000 \mathrm{~g}$ \\
\hline $3^{\text {rd }}$ week & 25.5 & 70 & $1100 \mathrm{~g}$ \\
\hline \multirow[t]{2}{*}{$4^{\text {th }}$ week } & 28 & 74 & $1000 \mathrm{~g}$ \\
\hline & & Total & 4.5 \\
\hline
\end{tabular}

Table.2 Month of November

\begin{tabular}{|c|c|c|c|}
\hline Weekly Data & Temperature $\left({ }^{\circ} \mathrm{C}\right)$ & Relative Humidity $(\%)$ & Yield of Mushroom $(\mathrm{Kg})$ \\
\hline $1^{\text {st }}$ week & $\mathbf{2 7}$ & $\mathbf{7 0}$ & $\mathbf{8 0 0} \mathbf{~ g}$ \\
\hline $2^{\text {nd }}$ week & $\mathbf{2 8 . 5}$ & $\mathbf{7 4}$ & $\mathbf{9 0 0} \mathbf{g}$ \\
\hline $3^{\text {rd }}$ week & $\mathbf{2 6 . 2 5}$ & $\mathbf{7 5}$ & $\mathbf{1 1 0 0 g}$ \\
\hline $4^{\text {th }}$ week & $\mathbf{2 7}$ & $\mathbf{7 2 . 5}$ & $\mathbf{1 2 0 0} \mathbf{g}$ \\
\hline & & & Total \\
\hline
\end{tabular}

Table.3 Month of December

\begin{tabular}{|c|c|c|c|}
\hline Weekly Data & Temperature $\left({ }^{\circ} \mathrm{C}\right)$ & Relative Humidity (\%) & Yield of Mushroom (Kg) \\
\hline $1^{\text {st }}$ week & 22.5 & 78 & $1000 \mathrm{~g}$ \\
\hline $2^{\text {nd }}$ week & 22 & 77.5 & $1500 \mathrm{~g}$ \\
\hline $3^{\text {rd }}$ week & 21.75 & 76 & $1500 \mathrm{~g}$ \\
\hline \multirow[t]{2}{*}{$4^{\text {th }}$ week } & 22 & 77 & $2000 \mathrm{~g}$ \\
\hline & & Total & 6 \\
\hline
\end{tabular}

Table.4 Month of January

\begin{tabular}{|c|c|c|c|}
\hline Weekly Data & Temperature $\left({ }^{\circ} \mathrm{C}\right)$ & Relative Humidity (\%) & Yield of Mushroom (Kg) \\
\hline $1^{\text {st }}$ week & 23 & 76 & $1000 \mathrm{~g}$ \\
\hline $2^{\text {nd }}$ week & 23.45 & 78.5 & $1500 \mathrm{~g}$ \\
\hline $3^{\text {rd }}$ week & 24 & 79 & $1500 \mathrm{~g}$ \\
\hline $4^{\text {th }}$ week & 22 & 74 & $1900 \mathrm{~g}$ \\
\hline & & Total & 5.9 \\
\hline
\end{tabular}

Table.5 Month of February

\begin{tabular}{|c|c|c|c|}
\hline Weekly Data & Temperature $\left({ }^{\circ} \mathrm{C}\right)$ & Relative Humidity (\%) & Yield of Mushroom $(\mathrm{Kg})$ \\
\hline $1^{\text {st }}$ week & 27 & 72 & $1400 \mathrm{~g}$ \\
\hline $2^{\text {nd }}$ week & 28.35 & 72.5 & $1200 \mathrm{~g}$ \\
\hline $3^{\text {rd }}$ week & 29 & 71 & $1100 \mathrm{~g}$ \\
\hline \multirow[t]{2}{*}{$4^{\text {th }}$ week } & 29.5 & 70 & $1000 \mathrm{~g}$ \\
\hline & & Total & 4.7 \\
\hline
\end{tabular}


Table.6 Month of March

\begin{tabular}{|c|c|c|c|}
\hline Weekly Data & Temperature $\left({ }^{\circ} \mathrm{C}\right)$ & $\begin{array}{l}\text { Relative Humidity } \\
(\%)\end{array}$ & Yield of Mushroom $(\mathrm{Kg})$ \\
\hline $1^{\text {st }}$ week & 30 & 69.5 & $1100 \mathrm{~g}$ \\
\hline $2^{\text {nd }}$ week & 32.5 & 70 & $1000 \mathrm{~g}$ \\
\hline $3^{\text {rd }}$ week & 34 & 68 & $800 \mathrm{~g}$ \\
\hline \multirow[t]{2}{*}{$4^{\text {th }}$ week } & 34.5 & 68.5 & $600 \mathrm{~g}$ \\
\hline & & Total & 3.5 \\
\hline
\end{tabular}

Table.7 Month of April

\begin{tabular}{|c|c|c|c|}
\hline Weekly Data & Temperature $\left({ }^{\circ} \mathrm{C}\right)$ & $\begin{array}{l}\text { Relative Humidity } \\
\qquad(\%)\end{array}$ & Yield of Mushroom (Kg) \\
\hline $1^{\text {st }}$ week & 34 & 68 & $800 \mathrm{~g}$ \\
\hline $2^{\text {nd }}$ week & 35.5 & 67 & $700 \mathrm{~g}$ \\
\hline $3^{\text {rd }}$ week & 35 & 67.5 & $750 \mathrm{~g}$ \\
\hline $4^{\text {th }}$ week & 36 & 66 & $700 \mathrm{~g}$ \\
\hline & & Total & 3 \\
\hline
\end{tabular}

Table.8 Month of May

\begin{tabular}{|c|c|c|c|}
\hline Weekly Data & Temperature $\left({ }^{\circ} \mathrm{C}\right)$ & Relative Humidity (\%) & Yield of Mushroom (Kg) \\
\hline $1^{\text {st }}$ week & 38 & 64 & $500 \mathrm{~g}$ \\
\hline $2^{\text {nd }}$ week & 40 & 62.5 & $400 \mathrm{~g}$ \\
\hline $3^{\text {rd }}$ week & 41.5 & 60 & $300 \mathrm{~g}$ \\
\hline $4^{\text {th }}$ week & 42 & 55.5 & $300 \mathrm{~g}$ \\
\hline & & Total & 1.5 \\
\hline
\end{tabular}

Fig.1 Mushroom yield

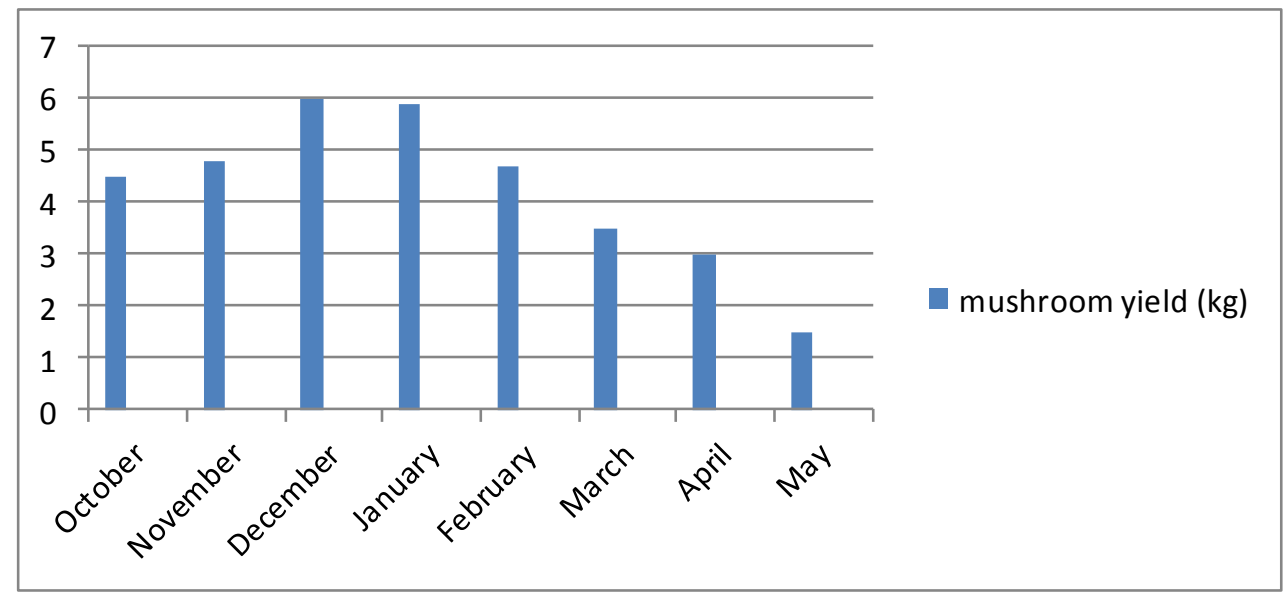


Table 3 and 4 shows the positive effect of temperature and relative humidity on the mycelial growth. High yield were recorded during December and January.

Low yield were recorded during April and May and those mushrooms were showed unshaped, shriveled, malformed and the same one were not suitable for marketing.

\section{References}

1. Block, S. S., Tsao, G. and Han, L. 1959. Experiments in the cultivation of Pleurotus ostreatus.. Mush. Res., 4: 309-325.

2. Quimio, T. H. 1977. Indoor cultivation of Pleurotus ostreatus. Philippine Agriculturist. 61: 253-262. Rajarathnam, S. and Bano, Z. 1987. Biological significance of natural celfulosic wastes degraded by Pleurotus mushroom. In: Science and Cultivation Technology ofEdjbe Fungi. T. N. Kaul and B. M. Kapur (eds.). RRL, CSIR, Jammu Tawai, pp. 295-304.

3. Rangad, C. O. and Jandaik, C. L. 1977. Cultural studies on some Pleurotus species. Ind. J. Mush., 3: 13-17.
4. Singh, M. P. 1997. Studies on Biodegradation of compost and growth behaviour of oyster mushroom. Ph.D. Thesis, Paunjab University, Chandjgarh, Jndja.

5. Singh, M. P. and Kaushal, S. C. 2001. Common grass -a potent substrate for cultivation of oyster mushroom. Mush. Res,, 10: 43-45.

6. Sohi, H.S., and Upadhyay, R.C. 1989. Effect of temperature on myceljal growth of Pleurotus species and their yield performance on selected substrate. Mushroom sci. Xll (Part Il): 49-56 Zadrazil, F. 1976. The ecology and industrial production of Pleurotus ostreatus, Pleurotus florida, Pleurotus conucopiae and Pleurotus eryngii.Mush. Sci., 9: 621-652.

7. Zadrazil, F. 1978. Cultivation of Pleurotus. In: The Biology and Cultivation of Edib/e mushrooms. S.

8. T. Chang and W. A. Hayes (eds.). Academic Press, New York. Pp. 521557.

9. Zadrazil, E 1980. Conversion of different plant wastes into feed by basidiomycetes. Eur. J. App/.

Microbiol. Biotechnol., 9: 243-248. (Received- June, 2006; AcceptedSeptember, 2006).

\section{How to cite this article:}

Chitra, K., B. Sathyaparvathavarthini, S. Mahalakshmi, R. Kamali, P.T. Sharavanan, C. Balisasikumar and Dhanalakshmi, K. 2018. Effect of Abiotic Factors on Oyster Mushroom Production (Pleurotus Species). Int.J.Curr.Microbiol.App.Sci. 7(07): 1032-1036. doi: https://doi.org/10.20546/ijcmas.2018.707.125 